Article

\title{
Combined Effects of Lipophilic Phycotoxins (Okadaic Acid, Azapsiracid-1 and Yessotoxin) on Human Intestinal Cells Models
}

\author{
Pierre-Jean Ferron ${ }^{1, *}$, Kevin Dumazeau ${ }^{1}$, Jean-François Beaulieu ${ }^{2}$, Ludovic Le Hégarat ${ }^{1}$ \\ and Valérie Fessard ${ }^{1}$ \\ 1 Toxicology of Contaminants Unit, French Agency for Food, Environmental and Occupational Health \& \\ Safety, Fougères 35300, France; kevin.dumazeau@gmail.com (K.D.); ludovic.lehegarat@anses.fr (L.L.H.); \\ valerie.fessard@anses.fr (V.F.) \\ 2 Laboratory of Intestinal Physiopathology, University of Sherbrooke, Sherbrooke, QC J1G 0A2, Canada; \\ jean-francois.beaulieu@usherbrooke.ca \\ * Correspondence: ferron.pj@gmail.com; Tel.: +33-02-99-17-27-47
}

Academic Editor: Luis Botana

Received: 14 October 2015; Accepted: 1 February 2016; Published: 19 February 2016

\begin{abstract}
Phycotoxins are monitored in seafood because they can cause food poisonings in humans. Phycotoxins do not only occur singly but also as mixtures in shellfish. The aim of this study was to evaluate the in vitro toxic interactions of binary combinations of three lipophilic phycotoxins commonly found in Europe (okadaic acid (OA), yessotoxin (YTX) and azaspiracid-1 (AZA-1)) using the neutral red uptake assay on two human intestinal cell models, Caco-2 and the human intestinal epithelial crypt-like cells (HIEC). Based on the cytotoxicity of individual toxins, we studied the interactions between toxins in binary mixtures using the combination index-isobologram equation, a method widely used in pharmacology to study drug interactions. This method quantitatively classifies interactions between toxins in mixtures as synergistic, additive or antagonistic. AZA-1/OA, and YTX/OA mixtures showed increasing antagonism with increasing toxin concentrations. In contrast, the AZA-1/YTX mixture showed increasing synergism with increasing concentrations, especially for mixtures with high YTX concentrations. These results highlight the hazard potency of AZA-1/YTX mixtures with regard to seafood intoxication.
\end{abstract}

Keywords: lipophilic phycotoxins; cytotoxicity; enterocytes; mixtures

\section{Introduction}

Phycotoxins are secondary metabolites produced by some phytoplanktonic unicellular algae. Due to their accumulation in filtering shellfish, several acute food intoxications following human consumption of contaminated shellfish have been well documented [1]. Phycotoxins are classified into hydrophilic and lipophilic groups according to their chemical properties. The EFSA (European Food and Safety Authority) report on marine biotoxins established five classes of toxins in the lipophilic group: okadaic acid (OA) and its analogs, azaspiracids (AZAs), pectenotoxins (PTXs), yessotoxins (YTXs) and spirolides (SPX) [2]. While the effects of OA and AZAs caused in humans have been well described, the effects caused by PTX-2, YTX and SPX still remain unclear, since there is no conclusive proof of human intoxication [1,3]. OA and its analogs, the dinophysistoxins, are polyethers responsible for the diarrhetic shellfish poisoning (DSP), causing symptoms such as nausea, severe diarrhea and abdominal pain [4]. These toxins are found worldwide and are protein phosphatase (PP) inhibitors (primarily PP2A, and to a lesser extent PP1 [5]. AZAs are composed of a spiro-ring assembly, a cyclic amino group and a carboxylic function. They are responsible for azaspiracid poisoning (AZP) [6] with 
symptoms similar to DSP (nausea and diarrhea), except that neurotoxicity has also been reported during in vivo experiments in mice [7]. Azaspiracids are relatively less common in seafood and have been described only sporadically in some areas in Europe [6], North America [8], Asia [9] and in northwestern Africa [10]. Nevertheless, the major AZA-producing species Azadinium sp. [11] has a widespread geographical distribution [11,12], and reports on new toxic species and new AZA analogs are increasing [13]. Although the mode of action of the AZA group has not been elucidated, the AZA toxins have been shown to inhibit endocytosis [14] and induce cytoskeleton disorganization [15]. Yessotoxins (YTXs) are sulfated polyether toxins with a hydrophobic tail and are found in shellfish all over the world [16]. The mode of action of YTXs has not yet been characterized, but YTX is known to induce endoplasmic reticulum stress [17], apoptosis [18], and endocytosis inhibition [19]. OA, AZA and YTX analogs can co-occur in shellfish [20-22]. Since no data are available on the toxicity of OA, AZA-1 and YTX mixtures in humans, EFSA has recommended to investigate the effects of these possible combinations [2]. Thus far, the effects of binary mixtures of OA and YTX [23], OA and AZA-1 (Azaspiracid-1) [24], and YTX and AZA-1 [25], have been studied in mice. However, none of these studies showed toxic interactions. As in vivo studies require laboratory animals and do not enable studying a large range of mixtures combinations, we therefore investigated the combined effects of lipophilic toxins using an in vitro approach in order to supplement previous results obtained in vivo. OA, AZA-1 and YTX have been shown separately to induce alterations in the mouse intestine $[7,26,27]$. Therefore, we conducted in vitro studies on human intestinal cells. Caco- 2 cells were selected as a model for human enterocytes, according to the OA toxicity results already available on this cell line [28,29] as well as for AZA-1 and YTX toxicity [30,31]. To address the combined effects on a non-cancerous human intestinal cell line, the human intestinal epithelial crypt-like cells (HIEC), the non-transformed, non-immortalized cell model isolated from intestines of human embryos [32] was selected. This cell model, under specific conditions, expresses specific crypt-cell markers, and can be maintained in culture with differentiated characteristics for up to 30 passages [33].

\section{Materials and Methods}

\subsection{Cell Cultures}

The Caco-2 cells HTB-37 were obtained from ATCC (American Type Culture Collection, LGC Standards, Molsheim, France). Cells were cultured in MEM medium containing 10\% fetal calf serum (FCS), $1 \%$ non-essential amino acids, $50 \mathrm{U} / \mathrm{mL}$ penicillin and $50 \mu \mathrm{g} / \mathrm{mL}$ streptomycin (Thermo Fisher Scientifc, Illkrich, France).

The HIEC cells were donated by Jean-François Beaulieu, previously described by [32]. HIEC were cultivated in OPTI-MEM medium (Thermofisher Scientific, Illkrich, France), supplemented with $20 \mathrm{mM}$ HEPES (Thermofischer Scientific), $10 \mathrm{mM}$ GlutaMAX (Thermofisher Scientific), $10 \mathrm{ng} / \mathrm{mL}$ EGF (Thermofisher Scientific) and 5\% fetal bovine serum (Cellect Gold; MP Biomedicals, Aurora, OH, USA). HIEC cells exhibit all the morphological and functional characteristics of normal human proliferative crypt cells and are considered to be undifferentiated crypt-like progenitor cells [34,35].

For assays, HIEC and Caco-2 cells were seeded at density of 30,000 cells $/ \mathrm{cm}^{2}$ and 90,000 cells $/ \mathrm{cm}^{2}$, respectively, in Nunc 96-well microplates (Thermo Fisher Scientific, Illkrich, France), 24 h prior to exposure.

\subsection{Toxins}

OA, AZA-1 and YTX were purchased from IMB/NRC (Halifax, NS, Canada). For assays, toxins were prepared in culture medium without FCS.

\subsection{Neutral Red Uptake Assay}

Neutral red powder (N4638) was purchased from Sigma-Aldrich (Lyon, France) and 0.1\% neutral red solution was prepared in Caco-2 and HIEC culture media. Following treatment with toxins, cells 
were rinsed with PBS, and $100 \mu \mathrm{L}$ of neutral red solution was added to each well and incubated for 2 $\mathrm{h}$ at $37^{\circ} \mathrm{C}$. Cells were then rinsed with PBS and $100 \mu \mathrm{L}$ of solubilization solution $(1 \%$ acetic acid in $50 \%$ ethanol) was added to each well. Absorbance was read at $540 \mathrm{~nm}$ and viability was calculated as percentage of mean absorbance (at least three independent experiments) relative to the control cells (growth medium with 5\% MeOH).

\subsection{Combinations of Toxins}

Cytotoxicity of combined phycotoxins was studied for three binary mixtures: OA and YTX, OA and AZA-1 and AZA-1 and YTX (Table 1). For each combination of toxins, four different ratios of toxins were tested, ranging from a ratio with high potency of one toxin to a ratio with high potency for the other. The chosen toxin ratios were based on preliminary individual cytotoxicity experiments.

Table 1. Cytotoxicity of okadaic acid (OA), azaspiracid-1 (AZA-1) and yessotoxin (YTX) determined using the neutral red uptake assay on Caco-2 and HIEC cells after $24 \mathrm{~h}$ exposure. Inhibitory concentration $50 \%\left(\mathrm{IC}_{50}\right.$ ) values of OA, AZA-1 and YTX in Caco-2 and HIEC cells from the neutral red uptake assay. $\mathrm{IC}_{50}$ values and $95 \%$ Confidence Interval $(\mathrm{CI})$ were calculated from six independent experiments performed in triplicate.

\begin{tabular}{ccccccc}
\hline \multirow{2}{*}{ Cytotoxicity } & \multicolumn{3}{c}{ Caco-2 } & \multicolumn{3}{c}{ HIEC } \\
\cline { 2 - 7 } & IC50 (nM) & $\mathbf{9 5 \%}$ CI & $\boldsymbol{n}$ & IC50 (nM) & $\mathbf{9 5 \% ~ C I ~}$ & $\boldsymbol{n}$ \\
\hline OA & 78.52 & $46.48-111.60$ & 6 & 65.29 & $49.14-81.45$ & 6 \\
AZA-1 & $4.03^{*}$ & $2.05-6.01$ & 6 & $12.52^{*}$ & $8.64-16.40$ & 6 \\
YTX & 4.08 & $1.18-7.83$ & 6 & 3.36 & $1.17-5.93$ & 6 \\
\hline
\end{tabular}

Symbol * indicate a significant difference at $p<0.05$ between the $\mathrm{IC}_{50}$ values of the two cell lines using a $t$ test.

\subsection{Data Analysis}

Cytotoxicity of individual phycotoxins. The dose-response cytotoxicity of each phycotoxin was modeled using a Hill slope model on GraphPad Prism 5 (GraphPad Software, La Jolla, USA, 2010). If the coefficient $m$, indicative of the shape of the dose-response curve, was $>1$ (sigmoid curve) and if the linear correlation coefficient of the model was greater than or equal to 0.9 , the inhibitory concentration $50 \%\left(\mathrm{IC}_{50}\right)$ was calculated.

Cytotoxicity of phycotoxin mixtures. For each phycotoxin, the dose-response cytotoxicity was modeled using the median-effect equation of the mass-action law described by Chou and Talalay [36]. The median-effect equation is defined by:

$$
\log \left(\frac{f a}{f u}\right)=m \log D-m \log D_{m}
$$

where $D$ is the dose, $D_{m}$ is the dose required for $50 \%$ inhibition, $F a$ is the fraction affected by the dose $D, m$ is a coefficient of the sigmoidicity of the dose effect, and $F u=1-F a$.

The combination index $(C I)$ method was used to analyze interactions between phycotoxins. Following Chou and Talalay (1984) [36], the CI method was calculated as follows:

$$
C I=\frac{(D)_{1}}{(D m)_{1}}+\frac{(D)_{2}}{(D m)_{2}}
$$

where $(D)_{1}$ and $(D)_{2}$ are the doses of the two mixed phycotoxins, and $(D m)_{1}$ and $(D m)_{2}$ are the doses of the individual phycotoxins, respectively. $C I<1, C I=1$ and $C I>1$ indicate if the mixture displays a synergistic, additive or antagonistic effects, respectively. $C I$ values were established for cytotoxicity percentages ranging from 5\% to 95\% (corresponding to $\mathrm{Fa}$ values ranging from 0.05 to 0.95 ). For $F a$ values of $0.25,0.50$ and 0.75 , we determined the dose reduction index (DRI) values. The DRI is a measure of how many fold the dose of each drug in a synergistic combination is reduced, 
for a given effect level, compared with the doses of each drug alone. The DRIs were only calculated when the $C I$ values indicated synergism. The dose-response analyses of phycotoxin mixtures and the CI/DRI calculation were performed using CompuSyn software, version 3.01 (ComboSyn Inc., Paramus, NJ, USA).

\section{Results}

\subsection{Individual Cytotoxicity of $O A, A Z A-1$ and $Y T X$}

HIEC and Caco-2 cells were exposed to phycotoxins OA, AZA-1 and YTX for $24 \mathrm{~h}$. The three phycotoxins showed a dose-dependent toxic effect on both cell lines (Table 1). On Caco-2 cells, toxins displayed $\mathrm{IC}_{50}$ values of $78.5 \mathrm{nM}$ for OA, $4.0 \mathrm{nM}$ for AZA-1 and $4.1 \mathrm{nM}$ for YTX. On HIEC, toxins displayed $\mathrm{IC}_{50}$ values of $65.3 \mathrm{nM}$ for OA, $12.5 \mathrm{nM}$ for AZA-1 and $3.4 \mathrm{nM}$ for YTX. The results for OA and YTX toxicity on the two cell types were similar, but AZA- $1 \mathrm{IC}_{50}$ values were significantly different in HIEC and Caco-2 cells, with a greater effect observed on Caco-2 cells.

\subsection{Combined Cytotoxicity of AZA-1 and YTX}

The type of interaction (synergism, additivity or antagonism) for binary mixtures of OA, AZA-1 and YTX were characterized using the CI method. Four ratios of toxins were tested using the neutral red uptake assay (Table 2). These ratios were arbitrary defined, according to $\mathrm{IC}_{50}$ values of individual toxins. As all toxins are not equally potent, molecular ratios were determined in order that, in a binary combination of two toxins $A$ and $B$, two mixtures will enhance toxicity mainly due to toxin $A$, and the two others will enhance toxicity mostly due to toxin $B$. Then, $C I$ values were calculated from $F a$ values of 0.05 (corresponding to $\mathrm{IC}_{05}$ ) to 0.95 (corresponding to $\mathrm{IC}_{95}$ ) (Figures 1-3). Dose-reduction indices (DRI) were calculated when synergism $(C I<1)$ was observed (Table 3$)$.

Table 2. Molar ratios of toxin concentrations used in binary mixtures.

\begin{tabular}{ccccc}
\hline \multirow{2}{*}{ Toxins Mixture } & \multicolumn{4}{c}{ Molar Combination Ratio } \\
\cline { 2 - 5 } & Mix 1 & Mix 2 & Mix 3 & Mix 4 \\
\hline AZA:YTX & $1: 0.8$ & $1: 1.3$ & $1: 2.4$ & $1: 3.6$ \\
AZA:OA & $1: 51$ & $1: 27.2$ & $1: 15.3$ & $1: 8.2$ \\
YTX:OA & $1: 26.5$ & $1: 14.1$ & $1: 7.9$ & $1: 4.2$ \\
\hline
\end{tabular}

AZA-1/YTX mixtures displayed a dose-dependent cytotoxicity on both Caco-2 and HIEC cells. Toxins interactions were analyzed using the CI method applied on cytotoxicity data (Figure 1). Figure 1A suggests that, in Caco-2 cells, in mixtures in which toxicity is mainly due to the presence of AZA-1, mixture 1 displayed additivity, while mixture 2 showed only a slight synergistic effect between $\mathrm{IC}_{10}$ and $\mathrm{IC}_{75}$ with a $\mathrm{CI}$ value ranging from 0.74 to 0.88 . For mixtures 3 and 4 with a toxic effect mainly induced by the presence of YTX, mixture 3 showed a slight synergistic effect, and even more pronounced in mixture 4 . Figure $1 \mathrm{~B}$ suggests that a synergistic effect occurred also in HIEC, and was mainly caused by mixtures where AZA-1 is the main toxic compound (Mix 1 and 2), and to a lesser degree with mixture 3 where YTX is the main toxic compound. The synergistic effect was even more pronounced as CI level reached a value of 0.3 . In general, CI values ranged between 0.9 and 0.3 , and synergism was greater at high toxic potency $(F a>0.5)$. Conversely to Caco- 2 cells, mixture 4 displayed additivity in HIEC cells.

The DRI values in Table 3 indicate for each toxin the fold reduction in the $\mathrm{IC}_{25}, \mathrm{IC}_{50}$ and $\mathrm{IC}_{75}$ values to apply in order to obtain the theoretical additive effect. Except for mixture 4 in HIEC cells and mixture 1 in Caco-2 cells, all mixtures displayed a synergistic effect. The combination index method allows calculating a theoretical dose reduction index, which can be applied as a factor on toxins concentration when an additive effect is considered. The DRI values for YTX in both Caco-2 
and HIEC is higher to the DRI values for AZA-1, suggesting that, in the mixture, YTX is more potent than AZA-1.

\section{AZA-1 - YTX}

\section{A. Caco-2}
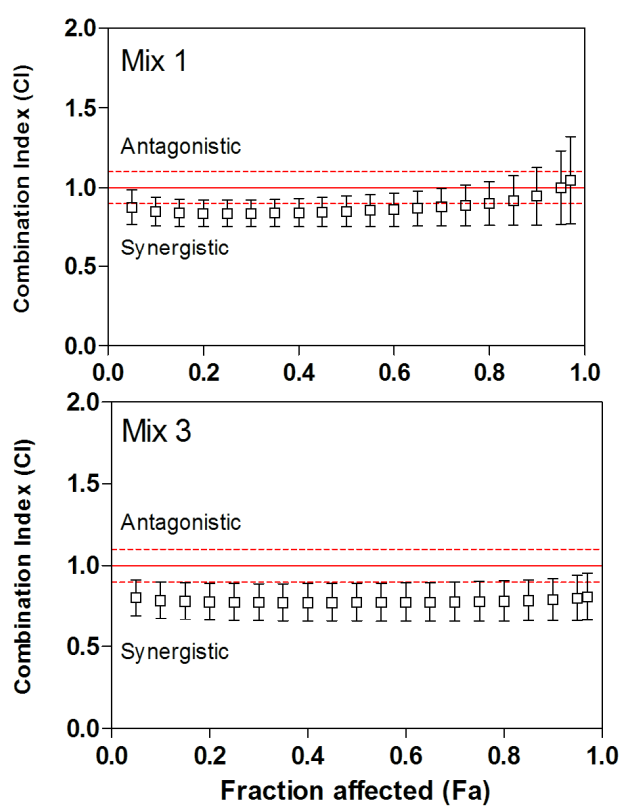

\section{B. HIEC}
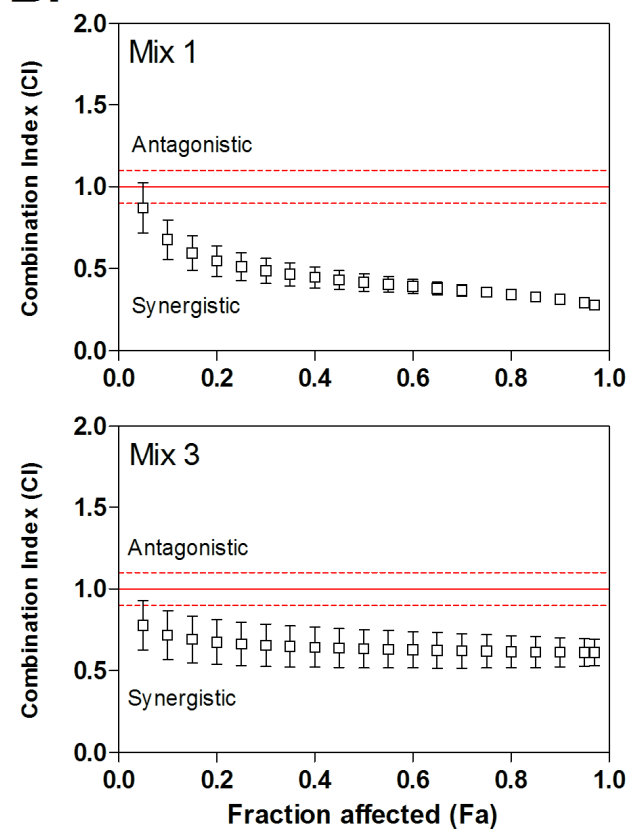
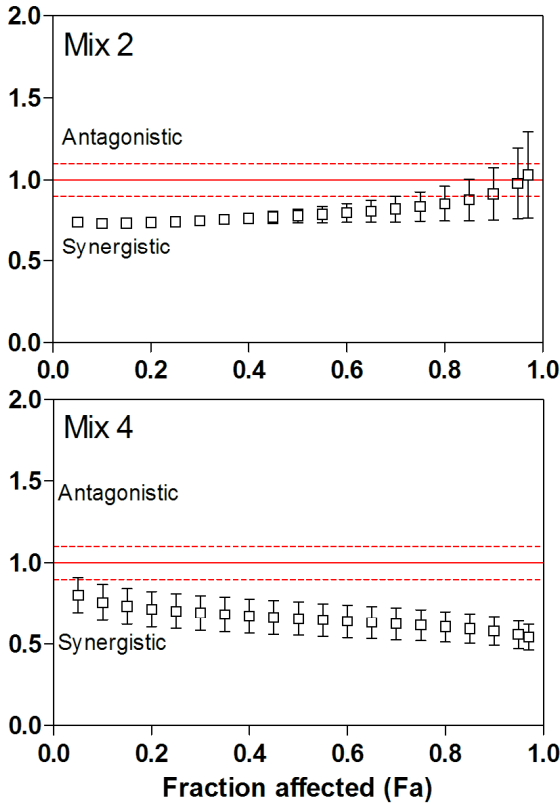

Fraction affected (Fa)
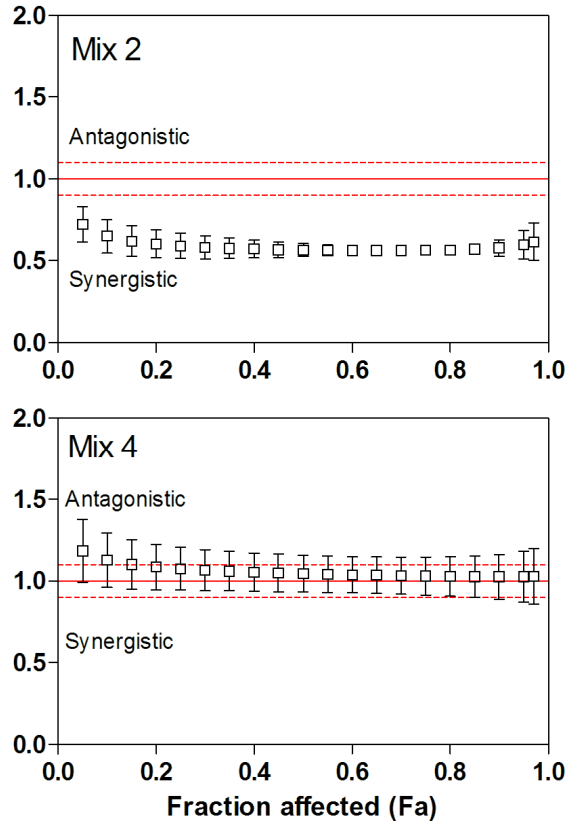

Figure 1. Combination index $(C I)$ plot for binary mixtures of azaspiracid-1 (AZA-1) and yessotoxin (YTX) in four different molar ratios. $C I$ values were calculated from fractional cytotoxicity $(F a)$ by computer modeling (CompuSyn) on $F a=0.05$ to 0.95 . $C I<1, C I=1$ and $C I>1$ indicate synergistic, additive and antagonistic effects, respectively. The vertical bar indicates the standard deviation for the three replicates. Dashed lines indicate upper and lower limit of additivity [36]. (A) Combinary index plots based on Caco-2 cells experiments; (B) Combinary index plots based on HIEC cells experiments. 


\section{AZA-1 - OA}

A.
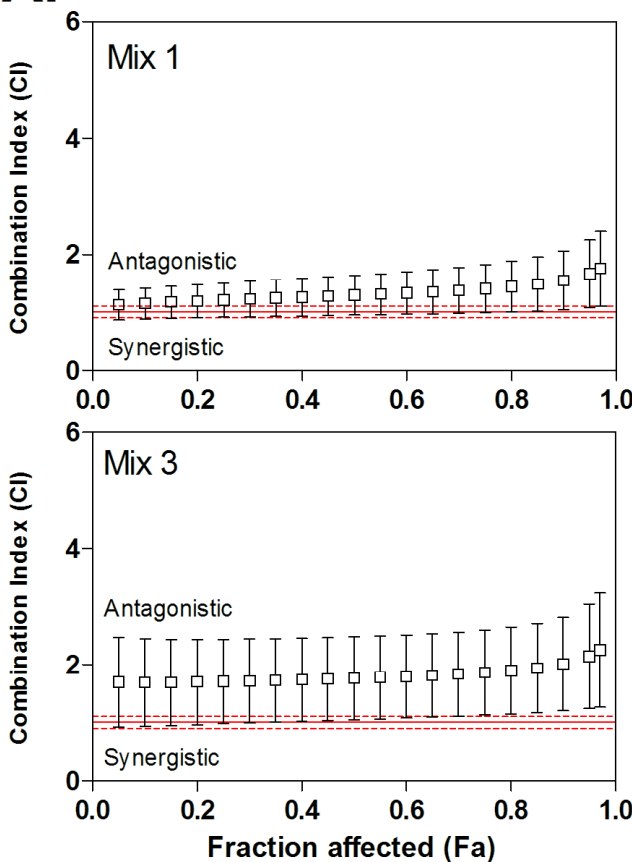

B.
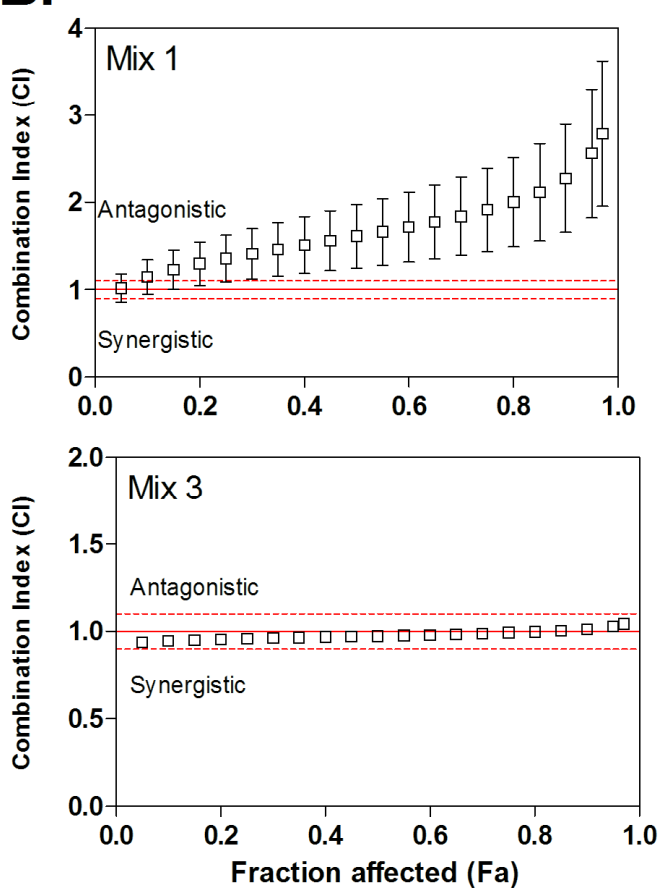
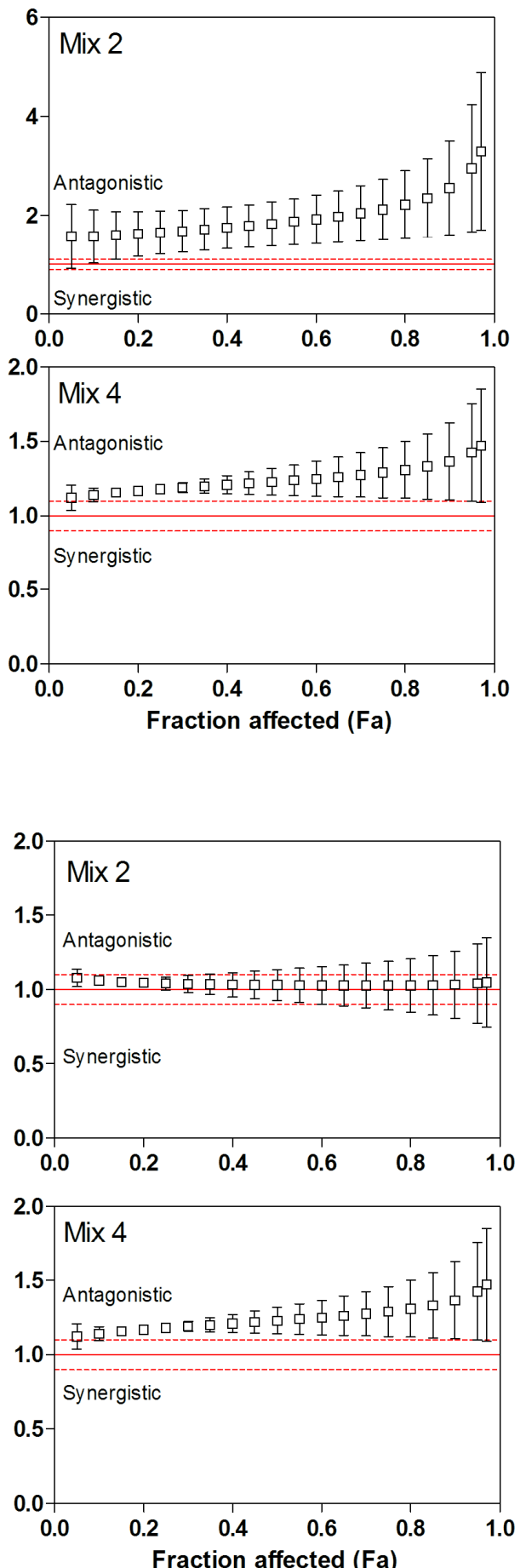

Figure 2. Combination index plot for binary mixtures of okadaic acid (OA) and azaspiracid-1 (AZA-1) at four different molar ratios. $C I$ values were calculated from fractional cytotoxicity $(F a)$ by computer modeling (CompuSyn) on $F a=0.05$ to 0.95 . $C I<1, C I=1$ and $C I>1$ indicate synergistic, additive and antagonistic effects, respectively. The vertical bar indicates the standard deviation for the three replicates. Dashed lines indicate upper and lower limit of additivity [36]. (A) Combinary index plots based on Caco-2 cells experiments; (B) Combinary index plots based on HIEC cells experiments. 

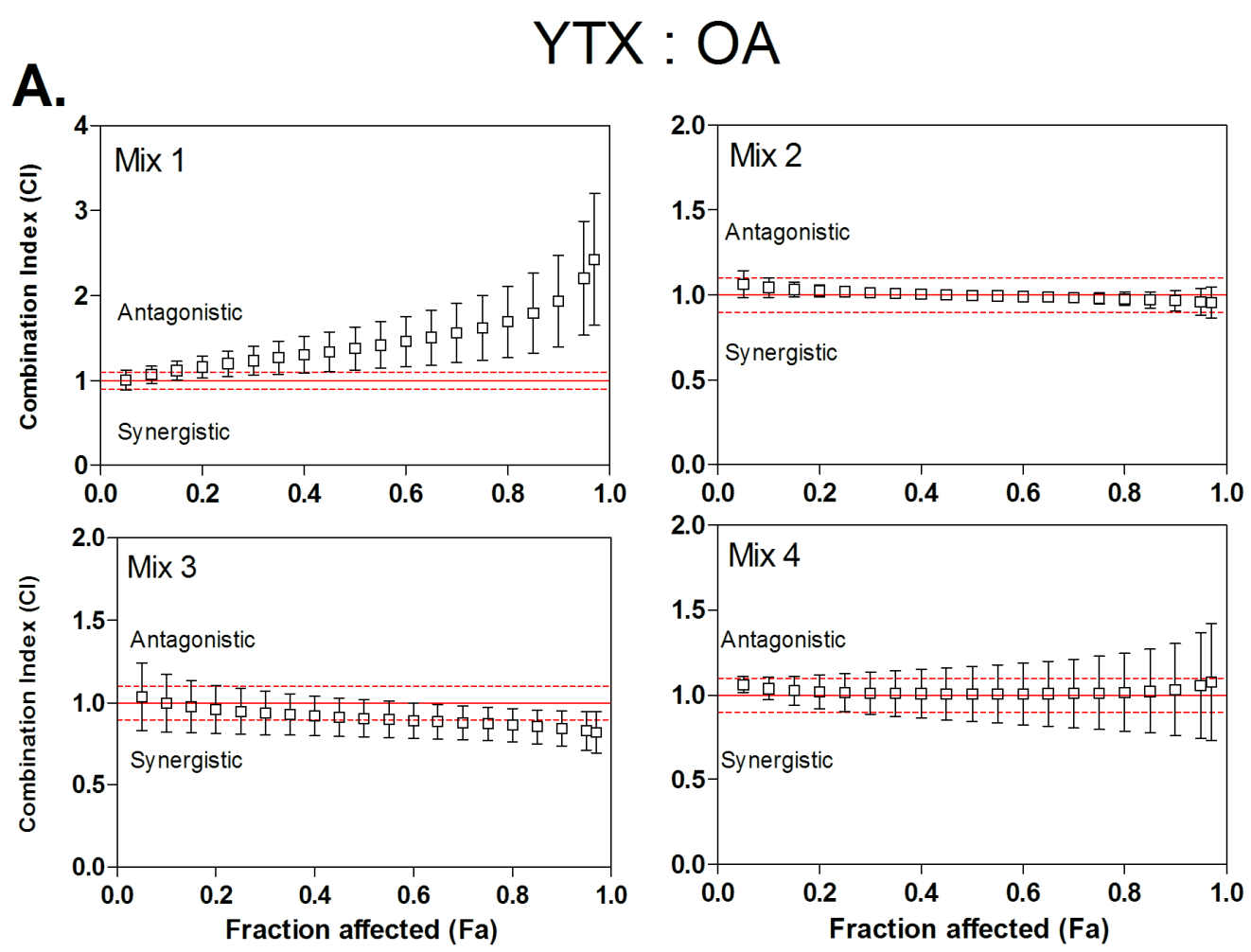

B.
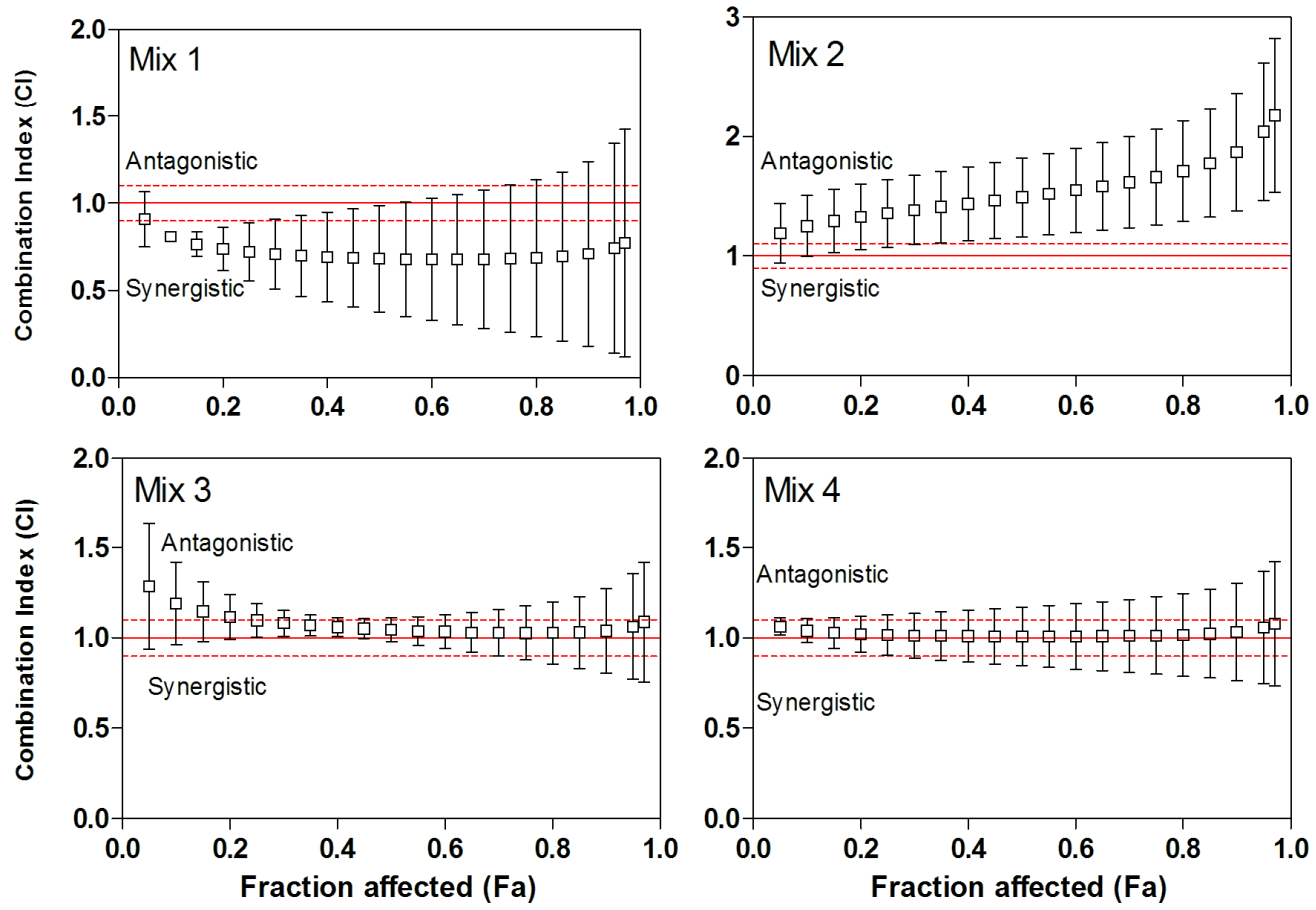

Figure 3. Combination index (CI) plot for binary mixtures of okadaic acid (OA) and yessotoxin (YTX) at four different molar ratios. $\mathrm{CI}$ values were calculated from fractional cytotoxicity $(\mathrm{Fa})$ by computer modeling (CompuSyn) on $F a=0.05$ to 0.95 . $C I<1, C I=1$ and $C I>1$ indicate synergistic, additive and antagonistic effects, respectively. The vertical bar indicates standards deviation between the three experiments. Dashed lines indicate upper and lower limit of additivity [36]. (A) Combinary index plots based on Caco-2 cells experiments; (B) Combinary index plots based on HIEC cells experiments. 
Table 3. Combination index (CI) values and dose-response index (DRI) values for binary mixtures of okadaic acid (OA), azaspiracid-1 (AZA-1) and yessotoxin (YTX) in Caco-2 and HIEC cells. CI values were calculated as described in Materials and Methods. DRI values were only calculated for toxin mixtures when synergistic effects were detected. DRI values were calculated for binary toxin mixtures by comparing the concentration required to reach $\mathrm{IC}_{25}, \mathrm{IC}_{50}$ and $\mathrm{IC}_{75}$ cytotoxicity. Values of DRI $>2$ indicate synergistic effects.

\begin{tabular}{|c|c|c|c|c|c|c|c|c|c|c|c|c|c|}
\hline \multirow{3}{*}{ Phycotoxins } & \multirow{3}{*}{ Ratio } & \multicolumn{6}{|c|}{ Caco-2 } & \multicolumn{6}{|c|}{ HIEC } \\
\hline & & \multicolumn{2}{|c|}{ IC25 } & \multicolumn{2}{|c|}{ IC50 } & \multicolumn{2}{|c|}{ IC75 } & \multicolumn{2}{|c|}{ IC25 } & \multicolumn{2}{|c|}{ IC50 } & \multicolumn{2}{|c|}{ IC75 } \\
\hline & & CI & DRI & CI & DRI & CI & DRI & CI & DRI & CI & DRI & CI & DRI \\
\hline \multicolumn{14}{|l|}{ AZA:YTX } \\
\hline Mix 1 & $1: 0.8$ & 0.84 & / & 0.85 & / & 0.88 & / & 0.51 & $3.1: 2.8$ & 0.42 & $3.4: 4.3$ & 0.36 & $3.8: 6.8$ \\
\hline Mix 2 & $1: 1.3$ & 0.74 & 3.9:2.1 & 0.78 & 2.0:4.0 & 0.83 & / & 0.59 & 2.3:3.9 & 0.57 & 2.3:5.2 & 0.56 & 2.3:7.2 \\
\hline $\operatorname{Mix} 3$ & $1: 2.4$ & 0.77 & $1.5: 5.0$ & 0.77 & $1.4: 4.9$ & 0.78 & $1.3: 4.8$ & 0.66 & $1.7: 5.2$ & 0.63 & $1.7: 7.5$ & 0.62 & $1.8: 10.9$ \\
\hline $\operatorname{Mix} 4$ & $1: 3.6$ & 0.7 & $1.4: 8.6$ & 0.66 & $1.5: 9.4$ & 0.61 & $1.4: 10.4$ & 1.07 & / & 1.04 & / & 1.03 & / \\
\hline \multicolumn{14}{|l|}{ AZA:OA } \\
\hline Mix 1 & $1: 8.2$ & 1.20 & / & 1.29 & / & 1.40 & / & 1.35 & / & 1.60 & / & 1.91 & / \\
\hline $\operatorname{Mix} 2$ & $1: 15.3$ & 1.64 & / & 1.82 & / & 2.11 & / & 1.04 & / & 1.00 & / & 1.02 & / \\
\hline Mix 3 & $1: 27.2$ & 1.70 & / & 1.76 & / & 1.86 & / & 0.95 & / & 0.97 & / & 1.00 & / \\
\hline Mix 4 & $1: 51$ & 1.66 & / & 1.85 & / & 2.13 & / & 1.17 & / & 1.22 & / & 1.28 & / \\
\hline \multicolumn{14}{|l|}{ YTX:OA } \\
\hline Mix 1 & $1: 4.2$ & 1.2 & / & 1.38 & / & 1.63 & / & 0.72 & $3.4: 1.8$ & 0.68 & 3.5:1.4 & 0.68 & $3.4: 1.2$ \\
\hline $\operatorname{Mix} 2$ & $1: 7.9$ & 1.02 & / & 1.00 & / & 0.98 & / & 1.35 & / & 1.49 & / & 1.66 & / \\
\hline $\operatorname{Mix} 3$ & $1: 14.1$ & 0.95 & / & 0.91 & 2.1:2.0 & 0.87 & / & 1.10 & / & 1.04 & / & 1.02 & / \\
\hline Mix 4 & $1: 26.5$ & 1.14 & / & 1.14 & / & 1.16 & / & 1.01 & / & 1.01 & / & 1.01 & / \\
\hline
\end{tabular}

\subsection{Combined Cytotoxicity of AZA-1 and $O A$}

AZA-1/OA mixtures displayed dose-dependent cytotoxicity on Caco-2 and HIEC cells. Toxins interactions were analyzed using the CI method applied on cytotoxicity data (Figure 2). Figure 2 suggests that mixtures of AZA-1 and OA displayed principally antagonistic cytotoxicity in Caco-2. Indeed, in Figure 2A, all mixtures, 1, 2, 3 and 4, show CI values ranging between 1.2 and 3.3 in Caco-2. In HIEC cells (Figure 2B), when the mixture is driven by one of the two toxins (mixture 1, where toxicity is mainly due to the presence of AZA-1, and mixture 4 where the toxicity is mainly due to the presence of $\mathrm{OA}$ ), an antagonistic cytotoxicity was observed with $C I$ values between 1 and 2.8. However, for mixtures 2 and 3 , the toxic effects of the two toxins were additive ( $C I$ between 0.8 and 1.2).

\subsection{Combined Cytotoxicity of YTX and $O A$}

YTX/OA mixtures displayed dose-dependent cytotoxicity on both Caco-2 and HIEC cells. Figure 3 suggests that mixtures of YTX and OA displayed different interaction profile depending on cell types and mixture composition. In Caco-2 cells (Figure 3A), mixtures 2-4 displayed additive effects, showing $C I$ values ranging between 0.8 and 1.2. In mixture 1 , where the toxic potency is driven by YTX, the combined effect was strongly antagonistic ( $\mathrm{CI}$ values up to 2 ) at high toxin concentrations ( $F a$ above 0.8 ).

In HIEC cells (Figure 3B), for mixtures 3 and 4, where the toxic potency is driven by OA, the combined cytotoxic effects were additive, with $C I$ values ranging between 1 and 1.28. However, for mixture 1, where the toxic potency is driven by YTX, the combined effect was synergistic, (CI values between 0.9 and 0.67 ) but with a large variability. On the contrary, for mixture 2, even if the toxicity is mainly due to high YTX concentration, an antagonistic effect was detected with $C I$ values increasing from 1.2 at $\mathrm{Fa} 0.05$ to 2.1 at $F a 0.95$.

\section{Discussion}

Phycotoxins are known to accumulate in shellfish, which may cause human seafood poisoning [2]. In 2008, Wang estimated that algal toxins caused more than 50,000-500,000 intoxication incidents per year, with an overall mortality rate of $1.5 \%$ [37]. Data indicate that lipophilic phycotoxins, including the OA, AZA and YTX groups, can co-occur in shellfish [20,21]. To date, risk assessment has been 
based on toxicity data from individual toxins; however, to address the issue of co-occurrence, the EFSA recommends studying the toxic effects of lipophilic phycotoxins in mixtures [2]. We therefore studied the interactions of binary mixtures of OA, AZA-1 and YTX on human intestinal cell models. Cytotoxicity of OA, AZA-1 and YTX mixtures was investigated using the neutral red uptake assay on the conventional intestinal model Caco-2 cell line and the intestinal cell line HIEC, which has only recently been used in toxicology studies [38].

OA, AZA-1 and YTX are cytotoxic towards Caco- 2 and HIEC cells. The $\mathrm{IC}_{50}$ of OA on HIEC and Caco-2 cells (65.29 nM and $78.52 \mathrm{nM}$, respectively) was close to the one we previously established on Caco-2 (49,67 nM [29]. The neutral red assay is based on the incorporation and binding of the supravital dye neutral red in the lysosomes. Therefore, the response of Caco-2 cells towards AZA-1 exposure using the neutral red assay, compared to the lack of response observed when other cytotoxicity assays are performed on this cell line [8,39], indicates that lysosomes may play a key role in AZA-1 cytotoxicity. Our results also showed that YTX is highly toxic on both intestinal cell lines, in contrast with the low toxicity observed in rodents in vivo. Previously, YTX has been reported to induce no toxic effects on the murine intestine neither by $10 \mathrm{mg} / \mathrm{kg}$ oral dose nor by lethal intraperitoneal doses [24]. Furthermore, the consumption of shellfish contaminated with YTX has never been involved in any case of human poisoning. Among the three toxins, YTX was the most potent toxin on HIEC cells, whereas YTX and AZA-1 showed equal toxicity on Caco-2 cells. Our in vitro results on intestinal cell models do not match with the toxic potency observed upon oral administration to mice. While OA and AZA-1 displayed a Lethal Dose $50\left(\mathrm{LD}_{50}\right)$ of $0.5-2 \mathrm{mg} / \mathrm{kg}$ on mice, with an obvious toxicity on the intestine $[27,40,41]$, YTX did not cause any death on mice, or intestinal toxicity at $\leqslant 10 \mathrm{mg} / \mathrm{kg}$ [42]. The toxicity of YTX detected on proliferative intestinal cells is probably driven by a specific pathway. It has been established that the kinase pathways, especially the MEK/ERK pathway, play an essential role in human intestinal cell survival [43]. JNK, and the kinase pathway induced by YTX in parapoptosis cell death may be involved in YTX cytotoxicity observed in human intestinal proliferative cells [44].

In our study, the combined effects of the binary mixtures of OA, AZA-1 and YTX were assessed with the CI method [36] using four different toxin ratios. The ratios of phycotoxins in shellfish is unpredictable [21]; we therefore tested several ratios for each toxin mixture to cover a wide range of contamination possibilities. The $C I$ values were calculated for different toxicity levels to quantify synergistic or antagonistic toxin interactions. When synergism was detected, a DRI value was determined for each toxin in the mixture [45]. Most of the combined effects of binary mixtures of phycotoxins were additive or antagonistic on Caco- 2 and $\mathrm{HIEC}$ cells at low $\left(\mathrm{IC}_{25}\right)$ or high $\left(\mathrm{IC}_{75}\right)$ toxin doses. A synergistic effect was only observed with AZA-1 and YTX combinations in both cell lines.

Our results showed that the mixtures of YTX and OA induced rather additive and in some cases antagonistic effects. These data confirm the observation reported from oral exposure of mice where no combined toxic effect was detected after repeated oral doses of $1 \mathrm{mg} / \mathrm{kg}$ YTX and $0.185 \mathrm{mg} / \mathrm{kg}$ of OA in comparison with individual toxins [23]. Similarly, Rodriguez et al. (2015) [46] studied recently the toxicity of OA (1-500 nM) in combination with $500 \mathrm{nM}$ YTX on human neuroblastoma cells but did not observed any evidence of synergism after $24 \mathrm{~h}$ of exposure although an increased toxicity was detected after $48 \mathrm{~h}$ of exposure. Therefore, we suggest that further investigations with a longer incubation time should be performed using our method as a longer treatment time could modify interactions and might induce different pathways.

While OA/AZA1 showed in our study rather an additive effect for the mixtures 2 and 3, an antagonistic effect was observed in HIEC cells when the mixtures contain a high level of one of the toxin (mixtures 1 and 4). Similarly, mice orally exposed to mixtures with up to $570 \mu \mathrm{g} / \mathrm{kg}$ AZA-1 and $880 \mu \mathrm{g} / \mathrm{kg}$ OA did not display any combined effects compared with mice exposed to individual toxins. Furthermore, when OA and AZA-1 are given simultaneously, their uptake through the gastrointestinal (GI) epithelium, as well as their toxicity in the GI tract, decreased [24,40]. Both our results and the ones obtained in vivo suggest that the presence of both OA and AZA-1 in contaminated shellfish may result in additive toxicity for consumers. 
AZA-1/YTX mixtures displayed a synergistic effect for most of the combinations tested. The DRI was calculated to determine the dose-reduction for AZA-1 and YTX in a synergistic combination at $\mathrm{IC}_{25}, \mathrm{IC}_{50}$ and $\mathrm{IC}_{75}$ [47]. For AZA-1/YTX mixtures, the DRI ranged from 1.7 to 10.9 and 1.3 to 10.4 in HIEC and Caco-2 cells, respectively, indicating a similar degree of synergy in both cell lines. For the risk assessment of mixtures, the calculation of magnitude of interaction is an important parameter [48]. Studies performed on mice have shown that oral administration of YTX ( 1 or $5 \mathrm{mg} / \mathrm{kg}$ ) combined with $200 \mu \mathrm{g} / \mathrm{kg}$ AZA-1 did not enhance the oral toxicity of AZA-1 alone. Similarly, absorption of YTX or AZA-1 was not increased when both toxins were administered together [25]. However, our results indicate that co-exposure of human intestinal cells to AZA-1 and YTX may induce higher toxicity than exposure to just one toxin. Indeed, AZA-1 and YTX share a common toxicological mechanism, namely cellular endocytosis. AZA-1 and YTX induce the accumulation of ECRA100 in MCF-7 cells at the same level of potency (1 mM) [31]; however, AZA-1 inhibits the formation of the late endosomes, whereas YTX alters an ulterior step of protein degradation [14]. Co-exposure to AZA-1 and YTX may thus strongly inhibit cellular endocytosis. This complementary effect on intracellular protein trafficking may explain the toxicological synergism of AZA-1 and YTX on HIEC and Caco-2 cells.

The present study showed that Caco-2 and HIEC cells are sensitive to OA, AZA-1 and YTX, with an acute toxicity dose-response. Although the $\mathrm{IC}_{50}$ values of OA and YTX were quite similar on the two cell lines, AZA-1 displayed higher toxic potency on HIEC cells. In contrast to previous in vivo results, YTX was a very active compound on both human intestinal cell lines, suggesting that a specific pathway could be involved in in vitro human models. The CI method was used to predict the effect of binary mixtures of phycotoxins. As observed in vivo, the effects of OA/AZA-1 and OA/YTX mixtures on human intestinal cells are rather additive and eventually antagonistic in few cases. However, the AZA-1/YTX mixture showed a synergistic interaction suggesting an additional risk when consuming co-contaminated shellfish with these toxins. However, our in vitro conclusion cannot be easily extrapolated to in vivo situations. As the CI-isobologram method requests a large number of assays to allow good computer modeling, further studies should be conducted in vivo to study AZA-1 and YTX interactions, using such mathematical model. The CI-isobologram method can quantify the interactions of the toxicological effects in mixtures of up to five drugs [45]. Because phycotoxins frequently occur in mixtures in shellfish meat [21,22], evaluation of toxicological interactions between lipophilic phycotoxins OA, AZA, PTX-2 and YTX in tertiary and quaternary combinations is the next step in phycotoxin mixture studies. Similar experiments have been conducted on mycotoxin mixtures and have shown that low doses of mycotoxins in food and diet may be more toxic than predicted from individual mycotoxins [49].

\section{Conclusions}

Based on neutral red uptake assay, OA, AZA-1 and YTX induced cytotoxicity on both Caco-2 and HIEC cell lines. Binary combinations of OA and AZA- 1 and OA and YTX showed an additive and, in few cases, an antagonistic effect using the concept of combination index on our models. However, data analysis claimed synergism between AZA-1 and YTX on both Caco-2 and HIEC cells. Our in vitro findings could not enable any extrapolation to in vivo situations without further investigation, including a clear characterization of toxins mechanisms of action in mixtures.

Acknowledgments: Elizabeth Herring, Eric Tremblay and Blanche Senicourt from the Laboratory of Intestinal Physiopathology from Sherbrooke University (Canada) are gratefully acknowledged.

Author Contributions: Pierre-Jean Ferron conceived, designed, and analyzed the experiments. Kevin Dumazeau and Pierre-Jean Ferron performed the experiments. Jean-François Beaulieu provide HIEC cells, experimental facilities and advices. Pierre-Jean Ferron, Ludovic Le Hégarat and Valérie Fessard wrote the paper.

Conflicts of Interest: The authors declare no conflict of interest. 


\section{References}

1. Rossini, G.P.; Hess, P. Phycotoxins: Chemistry, mechanisms of action and shellfish poisoning. In Molecular, Clinical and Environmental Toxicology; Luch, A., Ed.; Birkhäuser: Basel, Switzerland, 2010; pp. 65-122.

2. Marine Biotoxins in Shellfish-Summary on Regulated Marine Biotoxins. Available online: http://www. elika.net/datos/articulos/archivo_en448/marinebiotoxins_en.pdf (accessed on 19 February 2016).

3. Dominguez, H.J.; Paz, B.; Daranas, A.H.; Norte, M.; Franco, J.M.; Fernández, J.J. Dinoflagellate polyether within the yessotoxin, pectenotoxin and okadaic acid toxin groups: Characterization, analysis and human health implications. Toxicon 2010, 56, 191-217. [CrossRef] [PubMed]

4. Yasumoto, T.; Murata, M.; Oshima, Y.; Sano, M.; Matsumoto, G.K.; Clardy, J. Diarrhetic shellfish toxins. Tetrahedron 1985, 41, 1019-1025. [CrossRef]

5. Dounay, A.B.; Forsyth, C.J. Okadaic acid: The archetypal serine/threonine protein phosphatase inhibitor. Curr. Med. Chem. 2002, 9, 1939-1980. [CrossRef] [PubMed]

6. Furey, A.; O'Doherty, S.; O'Callaghan, K.; Lehane, M.; James, K.J. Azaspiracid poisoning (AZP) toxins in shellfish: Toxicological and health considerations. Toxicon Off. J. Int. Soc. Toxinol. 2010, 56, 173-190. [CrossRef] [PubMed]

7. Ito, E.; Satake, M.; Ofuji, K.; Kurita, N.; McMahon, T.; James, K.; Yasumoto, T. Multiple organ damage caused by a new toxin azaspiracid, isolated from mussels produced in Ireland. Toxicon 2000, 38, 917-930. [CrossRef]

8. Twiner, M.J.; Rehmann, N.; Hess, P.; Doucette, G.J. Azaspiracid shellfish poisoning: A review on the chemistry, ecology, and toxicology with an emphasis on human health impacts. Mar. Drugs 2008, 6, 39-72. [CrossRef] [PubMed]

9. Gu, H.; Luo, Z.; Krock, B.; Witt, M.; Tillmann, U. Morphology, phylogeny and azaspiracid profile of Azadinium poporum (Dinophyceae) from the China Sea. Harmful Algae 2013, 64-75. [CrossRef]

10. Taleb, H.; Vale, P.; Amanhir, R.; Benhadouch, A.; Sagou, R.; Chafik, A. First detection of azaspiracids in mussels in North West Africa. J. Shellfish Res. 2006, 25, 1067-1070.

11. Tillmann, U.; Elbrächter, M.; Krock, B.; John, U.; Cembella, A. Azadinium spinosum gen. et sp. nov. (Dinophyceae) identified as a primary producer of azaspiracid toxins. Eur. J. Phycol. 2009, 44, 63-79. [CrossRef]

12. Potvin, É.; Jeong, H.J.; Kang, N.S.; Tillmann, U.; Krock, B. First report of the photosynthetic dinoflagellate genus Azadinium in the Pacific Ocean: Morphology and molecular characterization of Azadinium cf. poporum. J. Eukaryot. Microbiol. 2012, 59, 145-156. [CrossRef] [PubMed]

13. Krock, B.; Tillmann, U.; Witt, M.; Gu, H. Azaspiracid variability of Azadinium poporum (Dinophyceae) from the China Sea. Harmful Algae 2014, 36, 22-28. [CrossRef]

14. Sala, G.L.; Bellocci, M.; Callegari, F.; Rossini, G.P. Azaspiracid-1 inhibits the maturation of cathepsin D in mammalian cells. Chem. Res. Toxicol. 2013, 26, 444-455. [CrossRef] [PubMed]

15. Vilariño, N. Marine toxins and the cytoskeleton: Azaspiracids. FEBS J. 2008, 275, 6075-6081. [CrossRef] [PubMed]

16. Paz, B.; Daranas, A.H.; Norte, M.; Riobó, P.; José, M.F.; José, J.F. Yessotoxins, a group of marine polyether toxins: An overview. Mar. Drugs 2008, 6, 73-102. [CrossRef] [PubMed]

17. Rubiolo, J.A.; López-Alonso, H.; Martínez, P.; Millán, A.; Cagide, E.; Vieytes, M.R.; Vega, F.V.; Botana, L.M. Yessotoxin induces ER-stress followed by autophagic cell death in glioma cells mediated by mTOR and BNIP3. Cell. Signal. 2014, 26, 419-432. [CrossRef] [PubMed]

18. Korsnes, M.S. Yessotoxin as a tool to study induction of multiple cell death pathways. Toxins 2012, 4, 568-579. [CrossRef] [PubMed]

19. Callegari, F.; Rossini, G.P. Yessotoxin inhibits the complete degradation of E-cadherin. Toxicology 2008, 244, 133-144. [CrossRef] [PubMed]

20. Amzil, Z.; Sibat, M.; Royer, F.; Savar, V. First report on azaspiracid and yessotoxin groups detection in French shellfish. Toxicon 2008, 52, 39-48. [CrossRef] [PubMed]

21. Trainer, V.; Moore, L.; Bill, B.; Adams, N.; Harrington, N.; Borchert, J.; da Silva, D.; Eberhart, B.-T. Diarrhetic shellfish toxins and other lipophilic toxins of human health concern in Washington State. Mar. Drugs 2013, 11, 1815-1835. [CrossRef] [PubMed] 
22. Zamorano, R.; Marín, M.; Cabrera, F.; Figueroa, D.; Contreras, C.; Barriga, A.; Lagos, N.; García, C. Determination of the variability of both hydrophilic and lipophilic toxins in endemic wild bivalves and carnivorous gastropods from the Southern part of Chile. Food Addit. Contam. Part A 2013, 30, 1660-1677. [CrossRef] [PubMed]

23. Sosa, S.; Ardizzone, M.; Beltramo, D.; Vita, F.; Dell'Ovo, V.; Barreras, A.; Yasumoto, T.; Tubaro, A. Repeated oral co-exposure to yessotoxin and okadaic acid: A short term toxicity study in mice. Toxicon 2013, 76, 94-102. [CrossRef] [PubMed]

24. Aune, T.; Espenes, A.; Aasen, J.A.B.; Quilliam, M.A.; Hess, P.; Larsen, S. Study of possible combined toxic effects of azaspiracid-1 and okadaic acid in mice via the oral route. Toxicon 2012, 60, 895-906. [CrossRef] [PubMed]

25. Aasen, J.A.B.; Espenes, A.; Miles, C.O.; Samdal, I.A.; Hess, P.; Aune, T. Combined oral toxicity of azaspiracid-1 and yessotoxin in female NMRI mice. Toxicon 2011, 57, 909-917. [CrossRef] [PubMed]

26. Franchini, A.; Marchesini, E.; Poletti, R.; Ottaviani, E. Lethal and sub-lethal yessotoxin dose-induced morpho-functional alterations in intraperitoneal injected Swiss CD1 mice. Toxicon 2004, 44, 83-90. [CrossRef] [PubMed]

27. Tubaro, A.; Sosa, S.; Carbonatto, M.; Altinier, G.; Vita, F.; Melato, M.; Satake, M.; Yasumoto, T. Oral and intraperitoneal acute toxicity studies of yessotoxin and homoyessotoxins in mice. Toxicon 2003, 41, 783-792. [CrossRef]

28. Ehlers, A.; These, A.; Hessel, S.; Preiss-Weigert, A.; Lampen, A. Active elimination of the marine biotoxin okadaic acid by P-glycoprotein through an in vitro gastrointestinal barrier. Toxicol. Lett. 2014, 225, 311-317. [CrossRef] [PubMed]

29. Ferron, P.-J.; Hogeveen, K.; Fessard, V.; Hégarat, L. Comparative analysis of the cytotoxic effects of okadaic acid-group toxins on human intestinal cell lines. Mar. Drugs 2014, 12, 4616-4634. [CrossRef] [PubMed]

30. Leira, F.; Alvarez, C.; Cabado, A.G.; Vieites, J.M.; Vieytes, M.R.; Botana, L.M. Development of a F actin-based live-cell fluorimetric microplate assay for diarrhetic shellfish toxins. Anal. Biochem. 2003, 317, 129-135. [CrossRef]

31. Ronzitti, G.; Hess, P.; Rehmann, N.; Rossini, G.P. Azaspiracid-1 alters the E-cadherin pool in epithelial cells. Toxicol. Sci. Off. J. Soc. Toxicol. 2007, 95, 427-435. [CrossRef] [PubMed]

32. Beaulieu, J.-F.; Ménard, D. Isolation, characterization, and culture of normal human intestinal crypt and villus cells. Methods Mol. Biol. Clifton NJ 2012, 806, 157-173.

33. Perreault, N.; Beaulieu, J.F. Use of the dissociating enzyme thermolysin to generate viable human normal intestinal epithelial cell cultures. Exp. Cell Res. 1996, 224, 354-364. [CrossRef] [PubMed]

34. Guezguez, A.; Paré, F.; Benoit, Y.D.; Basora, N.; Beaulieu, J.-F. Modulation of stemness in a human normal intestinal epithelial crypt cell line by activation of the WNT signaling pathway. Exp. Cell Res. 2014, 355-364. [CrossRef] [PubMed]

35. Pageot, L.-P.; Perreault, N.; Basora, N.; Francoeur, C.; Magny, P.; Beaulieu, J.-F. Human cell models to study small intestinal functions: Recapitulation of the crypt-villus axis. Microsc. Res. Tech. 2000, 49, $394-406$. [CrossRef]

36. Chou, T.C.; Talalay, P. Quantitative analysis of dose-effect relationships: the combined effects of multiple drugs or enzyme inhibitors. Adv. Enzyme Regul. 1984, 22, 27-55. [CrossRef]

37. Wang, D.-Z. Neurotoxins from marine dinoflagellates: A brief review. Mar. Drugs 2008, 6, 349-371. [CrossRef] [PubMed]

38. Takenaka, T.; Harada, N.; Kuze, J.; Chiba, M.; Iwao, T.; Matsunaga, T. Human small intestinal epithelial cells differentiated from adult intestinal stem cells as a novel system for predicting oral drug absorption in humans. Drug Metab. Dispos. Biol. Fate Chem. 2014, 42, 1947-1954. [CrossRef] [PubMed]

39. Sérandour, A.-L.; Ledreux, A.; Morin, B.; Derick, S.; Augier, E.; Lanceleur, R.; Hamlaoui, S.; Moukha, S.; Furger, C.; Biré, R.; et al. Collaborative study for the detection of toxic compounds in shellfish extracts using cell-based assays. Part I: Screening strategy and pre-validation study with lipophilic marine toxins. Anal. Bioanal. Chem. 2012, 403, 1983-1993. [CrossRef] [PubMed]

40. Azaspiracids-Toxicological Evaluation, Test Methods and Identification of the Source Organism (ASTOX II). Available online: http://oar.marine.ie/handle/10793/970 (accessed on 19 February 2016).

41. Le Hégarat, L.; Jacquin, A.-G.; Bazin, E.; Fessard, V. Genotoxicity of the marine toxin okadaic acid, in human Caco-2 cells and in mice gut cells. Environ. Toxicol. 2006, 21, 55-64. [CrossRef] [PubMed] 
42. Aune, T.; Sørby, R.; Yasumoto, T.; Ramstad, H.; Landsverk, T. Comparison of oral and intraperitoneal toxicity of yessotoxin towards mice. Toxicon 2002, 40, 77-82. [CrossRef]

43. Gauthier, R.; Harnois, C.; Drolet, J.F.; Reed, J.C.; Vézina, A.; Vachon, P.H. Human intestinal epithelial cell survival: Differentiation state-specific control mechanisms. Am. J. Physiol. Cell Physiol. 2001, 280, C1540-C1554. [PubMed]

44. Korsnes, M.S.; Espenes, A.; Hetland, D.L.; Hermansen, L.C. Paraptosis-like cell death induced by yessotoxin. Toxicol. In Vitro 2011, 25, 1764-1770. [CrossRef] [PubMed]

45. Chou, T.-C. Theoretical basis, experimental design, and computerized simulation of synergism and antagonism in drug combination studies. Pharmacol. Rev. 2006, 58, 621-681. [CrossRef] [PubMed]

46. Rodríguez, L.; González, V.; Martínez, A.; Paz, B.; Lago, J.; Cordeiro, V.; Blanco, L.; Vieites, J.; Cabado, A. Occurrence of lipophilic marine toxins in shellfish from galicia (NW of Spain) and Synergies among them. Mar. Drugs 2015, 13, 1666-1687. [CrossRef] [PubMed]

47. Chou, T.-C. Frequently asked questions in drug combinations and the mass-action law-based answers. Synergy 2014, 1, 3-21. [CrossRef]

48. Boobis, A.; Budinsky, R.; Collie, S.; Crofton, K.; Embry, M.; Felter, S.; Hertzberg, R.; Kopp, D.; Mihlan, G.; Mumtaz, M.; et al. Critical analysis of literature on low-dose synergy for use in screening chemical mixtures for risk assessment. Crit. Rev. Toxicol. 2011, 41, 369-383. [CrossRef] [PubMed]

49. Alassane-Kpembi, I.; Kolf-Clauw, M.; Gauthier, T.; Abrami, R.; Abiola, F.A.; Oswald, I.P.; Puel, O. New insights into mycotoxin mixtures: The toxicity of low doses of Type B trichothecenes on intestinal epithelial cells is synergistic. Toxicol. Appl. Pharmacol. 2013, 272, 191-198. [CrossRef] [PubMed]

(C) 2016 by the authors; licensee MDPI, Basel, Switzerland. This article is an open access article distributed under the terms and conditions of the Creative Commons by Attribution (CC-BY) license (http://creativecommons.org/licenses/by/4.0/). 